\title{
CIRCADIAN RHYTHM OF ACID PHOSPHATASE IN MOUSE TESTIS LYSOSOMES
}

\author{
J. RUSSO \\ Instituto de Histología y Embriologia, \\ Facultad de Ciencias Médicas U.N.C., \\ Mendoza, Argentina \\ (Received 11 th August 1969, revised 20th February 1970)

\begin{abstract}
Summary. The lysosomal enzyme, acid phosphatase, presents a circadian rhythm in the mouse testis. The content of protein, water and dry matter does not change during the $24-\mathrm{hr}$ period, but there is an increase in the activity of the enzyme to midday and a decrease between 12.00 and 20.00 hours.

The function of this enzyme and its inverse relationship to the availability of LH are discussed.
\end{abstract}

\section{INTRODUCTION}

A phenomenon which repeats itself at given time intervals within a period of $24 \mathrm{hr}$, is said to obey a circadian rhythm (Pittendrigh, 1961; Halberg, Miffley, Stein, Panofsky \& Adkins, 1964). Circadian rhythms have been demonstrated for different organic functions (Kleithman, 1949; Halberg, 1953, 1957) and light, as a synchronizer, is known to be an important factor in gonadal function (Benoit, 1935; Bissonnette, 1937; Assenmacher \& Benoit, 1953) but it is unknown whether enzymatic activities follow any circadian rhythm in the testis.

In previous papers (Russo, 1967, 1968; Russo \& Burgos, 1969), intralysosomal acid phosphatase has been reported to play a rôle in the function of the testis. The work described here, was undertaken in order to find out whether lysosomal acid phosphatase follows a circadian rhythm in the mouse testis.

\section{MATERIAL AND METHODS}

For 60 days from birth, 120 male Swiss mice were kept on a $14 \mathrm{hr}$ light $/ 10 \mathrm{hr}$ dark regimen (light from 06.00 to 20.00 hours). At 15 days of age, they were separated from their mothers in groups of twenty per cage. At 60 days of age, they were decapitated at different times of the day: 08.00, 12.00, 16.00. 20.00, 24.00 and 04.00 hours. The testes were carefully removed and placed on ice after removing the epididymides. One testis of each animal was homogenized with a Potter-Elvehjem homogenizer in distilled water $(1 \mathrm{ml}$ for $10 \mathrm{mg}$ of tissue) to produce osmotic shock of the lysosomes. The homogenate was divided into aliquots for determination of proteins (Gornall, Bardowill \& David, 1932) and of acid phosphatase (Bodansky, 1932). The other testis of each animal 
was used for determination of water content by subtracting from the wet weights the figures obtained after drying to constant weight. The acid phosphatase activity was expressed in terms of $\mu$ g inorganic phosphorus/mg protein/ min of incubation.

\section{RESULTS}

The acid phosphatase activity presents evident variations at different times of the day. As shown in Table 1 and Text-fig. 1, it increases very significantly from 08.00 to 12.00 hours, when the activity reaches a peak; it then decreases between 12.00 and 20.00 hours and increases again slightly from 20.00 to 04.00 hours.

\section{TABLE 1}

PROTEIN, DRY MATTER, WATER AND ACID PHOSPHATASE CONTENT IN THE MOUSE TESTIS DURING THE 24-HR PERIOD

\begin{tabular}{|c|c|c|c|c|}
\hline Group & $\begin{array}{c}\text { Protein } \\
\text { (mg/g of tissue) }\end{array}$ & $\begin{array}{l}\text { Dry matter } \\
\text { (mg/g testis })\end{array}$ & $\begin{array}{c}\text { Water } \\
\text { (mg/g testis })\end{array}$ & 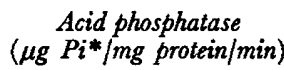 \\
\hline $\begin{array}{l}08.00 \text { hours } \\
12.00 \text { hours } \\
16.00 \text { hours } \\
20.00 \text { hours } \\
24.00 \text { hours } \\
04.00 \text { hours }\end{array}$ & $\begin{array}{l}125 \cdot 2 \pm 10 \cdot 0 \\
119.3 \pm 9.5 \\
120.7 \pm 3.2 \\
126.5 \pm 9 \cdot 6 \\
127.4 \pm 10 \cdot 2 \\
108 \cdot 8 \pm 13.4\end{array}$ & $\begin{array}{l}175 \cdot 2 \pm 7 \cdot 3 \\
183 \cdot 9 \pm 8 \cdot 2 \\
182 \cdot 9 \pm 8 \cdot 0 \\
183 \cdot 1 \pm 7 \cdot 9 \\
192 \cdot 3 \pm 10 \cdot 2 \\
171 \cdot 2 \pm 9 \cdot 5\end{array}$ & $\begin{array}{l}840 \pm 30 \\
815 \pm 28 \\
817 \pm 27 \\
816 \pm 25 \\
807 \pm 32 \\
860 \pm 37\end{array}$ & $\begin{array}{r}8 \cdot 37 \pm 1 \cdot 05 \\
11 \cdot 56 \pm 1 \cdot 10 \\
8 \cdot 92 \pm 0 \cdot 79 \\
7 \cdot 25 \pm 1 \cdot 00 \\
7.88 \pm 0 \cdot 85 \\
8.95 \pm 0 \cdot 70\end{array}$ \\
\hline
\end{tabular}

Student's $t$-test for acid phosphatase:

$t-4.5(P=0.01)$ at 08.00 to 12.00 hours.

$t-3.7(P=0.01)$ at 20.00 to 04.00 hours.

* Inorganic phosphorus.

The figures for protein, dry matter and water did not present significant changes during the light/dark regimen. The acid phosphatase activity varied according to a circadian rhythm.

Table 1 shows the protein, dry-matter and water content of the testis, expressed in $\mathrm{mg} / \mathrm{g}$ of wet weight. These parameters do not present variations at the different hours of the day studied, which indicates that the changes in specific acid phosphatase activity are a true property of the enzyme and/or the lysosomes.

\section{DISCUSSION}

The function of acid phosphatase in the mouse testis has been discussed in previous papers (Russo, 1967, 1968; Russo \& Burgos, 1969). The enzyme was shown to be localized in the Leydig cells and the Sertoli cells of different species (Russo, 1968); histochemical methods for ultrastructural study (Frank \& Christensen, 1968; Pasalaki, Szabo, Bácsi \& Ökros, 1968) afforded coincident results. Acid phosphatase is a useful marker of the lysosomes (De Duve, 1963; Novikoff, 1963). In the Sertoli cell, the function of the enzyme is related to the disposal of débris during and after spermiation, according to Lacy (1967) and Pasalaki et al. (1968). In the toad, it has been demonstrated (Russo \& Burgos, 1969) that human chorionic gonadotrophin (HCG) inhibits testicular acid phosphatase at the same time as it causes spermatozoa to be released from the Sertoli cell to appear in the cloacal fluid. In the mouse, HGG produces a decrease 
of this enzyme (Russo, 1968). In the hamster, mating produces a depression of testicular acid phosphatase (Burgos, Vitale-Calpe \& Russo, 1968) and causes liberation of luteinizing hormone (LH) by the hypophysis (Donoso \& Santolaya, 1969). In this animal, the LH and HCG also produce a depression of the acid phosphatase (Russo \& Burgos, 1970, unpublished observation).

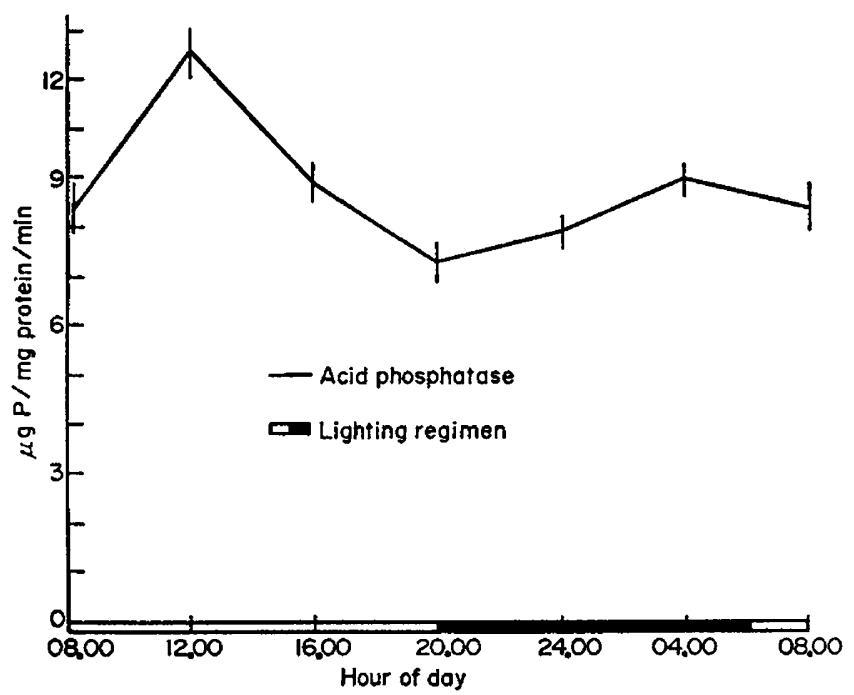

TExT-FTg. 1. The variations of acid phosphatase activity during a 24-hr period present a circadian rhythm related to the lighting regimen in the animal house.

In the Leydig cell, the function of the lysosomes is thought to be related to some step of steroid synthesis, as might be inferred from the results of Dietert \& Scallen (1969) and Frank \& Christensen (1968).

The effect of light on the gonad has been reported to be mediated by the hypothalamic-hypophysial axis (Benoit, 1935; Assenmacher \& Benoit, 1953). Renaud (1965) observed that darkness retards the spermiogenic effect of HCG in Cattinus virginianus virginianus L. Ferrand (1966) showed that darkness produces gonadal regression in fully mature Ligurinus chloris.

The circadian rhythm of the mouse testicular acid phosphatase is probably related to a control exerted by the pituitary gland through the gonadotrophins, since the enzymatic activity is high when the hormone in the blood is low. The following observations support this suggestion. Gopulatory activity reaches its peak between 18.00 and 24.00 hours (Russo, 1968), when acid phosphatase is at its minimum and the blood level of LH is highest (Donoso \& Santolaya, 1969) as a result of its being discharged from the hypophysis. In the amphibian, Leptodactylus chaquensis, testicular acid phosphatase activity exhibits seasonal variations. It is high during winter and low during summer (Russo, 1968). These changes are coincident with the winter testicular regression and summer breeding activity, respectively (Gei, 1948). Additional evidence in favour of a hypothalamic-hypophysial mechanism is provided by the finding that hypophysectomy produces an increase of acid phosphatase in the summer testis of L. chaquensis (Bertini, Russo \& Piezzi, 1969). 
On the basis of the information discussed above, we advance the hypothesis that testicular acid phosphatase is inversely dependent on the availability of LH.

\section{ACKNOWLEDGMENTS}

The author is indebted to Professor M. H. Burgos and Dr F. Sacerdote, for their interest and criticism.

This work was supported by Grant M 63-121 from the Population Council, U.S.A.

\section{REFERENCES}

Assenmacher, I. \& Benort, J. (1953) Répercussions de la section du tractus porto-tubéral hypophysaire sur la gonadostimulation par la lumière chez le canard domestique. C. r. hebd. Séanc. Acad. Sci., Paris, 236, 2002.

Benorr, J. (1935) Maturité sexuelle et ponte obtenues chez la cane domestique par l'éclairement artificiel. C. r. Séanc. Soc. Biol. 120, 905.

Bertini, F., Russo, J. \& Piezzi, R. S. (1969) Effect of hypophysectomy on the histology and acid phosphatase distribution in the testis of Leptodactylus chaquensis. Acta physiol. latinoam. 19, 22.

Bissonnette, T. H. (1937) Photoperiodicity in birds. Wilson Bull. 49, 241.

Bodansky, A. (1932) Determination of serum phosphatase. 7. biol. Chem. 99, 197.

Burgos, M. H., Vitale-Calpe, R. \& Russo, J. (1968) Effect of $L H$ in the seminiferous tubule at the subcellular level. In: Gonadotropins, p. 213. Ed. Eugenia Rosemberg. Geron X, Los Altos, California.

Ger, J. M. (1948) Los fenómenos ciclicos endocrinos sexuales de la rana criolla L. ocellatus. Acta zool. lilloana, 6, 283.

De Duve, CH. (1963) General properties of lysosomes. The lysosome concept. In: Lysosomes, p. 1. Ciba Fdn Symp. Churchill, London.

Dietert, S. E. \& Scallen, T. J. (1969) An ultrastructural and biochemical study of the effect of three inhibitors of cholesterol biosynthesis upon murine, adrenal gland and testis. I. Histochemical evidence for a lysosome response. 7. Cell Biol. 40, 44.

Donoso, A. O. \& Santolaya, R. C. (1969) Depletion of pituitary lh induced by coitus in the male hamster. Acta physiol. latinoam. 19, 70.

Ferrand, R. (1966) Effet de séjour à l'obscurité sur le testicule du verdier (Ligurinus chloris L). C. r. Séanc. Soc. Biol. 160, 1715.

Frank, A. L. \& Christensen, A. K. (1968) Localization of acid phosphatase in lipofuscin granules and possible autophagic vacuoles in interstitial cells of the guinea pig testes. F. Cell Biol. 36, 1.

Gornall, A. C., Bardowill, C. J. \& David, M. (1932) Determination of serum protein by means of the biuret reaction. F. biol. Chem. 99, 197.

HalBerg, F. (1953) Some physiological and clinical aspects of 24-hour periodicity. 7.-Lancet, 73, 20.

Halberg, F. (1957) Young NH-mice for the study of mitosis in intact liver. Experientia, 13, 502.

Halberg, F., Miffley, M., Strin, M., Panofsky, H. \& Adkins, G. (1964) Computer techniques in the study of biologic rhythms. Ann. N.Y. Acad. Sci. 115, 695.

Kieithman, N. (1949) Biological rhythms and cycles. Physiol. Rev. 29, 1.

LACY, D. (1967) The seminiferous tubule in mammals. Endeavour, 26, 101.

Novikorr, A. B. (1963) Lysosomes in the physiology and pathology of cells: contributions of staining methods. In: Lysosomes, p. 36. Ciba Fdn Symp. Churchill, London.

PASAlaki, Z., SzABo, D., BÁcsi, E. \& OKR"os, I. (1968) Hydrolytic enzymes during spermatogenesis in rat. An electron microscopy and histochemical study. J. Histochem. Cytochem. 14, 249.

Pittendrigh, C. S. (1961) Circadian rhythms and the circadian organisation of living systems. Cold Spring Harb. Symp. quant. Biol. 25, 159.

Renaud, D. (1965) Influences simultanées de la lumière et d'injections d'hormone gonadotrope sur le développement testiculaire de colins immatures (Oiseaux Galliformes Odontophoridés). Bull. Soc. Zool. Fr. 90, 417.

Russo, J. (1967) Acid and alkaline phosphatases of the mouse testis at different stages of post-natal development. Acta physiol. latinoam. 17, 302.

Russo, J. (1968) Localización, función y regulación de la fosfatasa ácida testicular. Doctoral thesis, U.N.C.

Russo, J. \& Burgos, M. H. (1969) Effect of HCG on the enzymic activity of toad testis. Gen. $\mathcal{E}^{\circ}$ compar. Endocr. 13, 185. 